MARTA DORENDA

Instytut Politologii UMK

\title{
Kto płaci za tanie ubrania?
}

$\mathbf{T}$

ransformacja ustrojowa i początek lat 90. przyniosły Polsce nowe zjawisko - zalew popkultury i zachłyśnięcie się tym, co zachodnie. Modny był zachwyt produktami, które oglądaliśmy w amerykańskich filmach, jednocześnie trzymając je w ręku lub posiadając na własnej półce. Koniec minionej dekady naznaczony jest przez przeciwieństwo tego stanu - pochwałę globalizacji zastąpił styl uznawany dotąd za alternatywny. To zgodnie z nim promujemy tzw. zdrowy tryb życia - segregujemy śmieci, by chronić planetę; potępiamy właścicielki futer, ponieważ leży nam na sercu los niewinnych zwierząt; unikamy koncernów, bo nie tylko zalewają świat jednolitą pseudokulturalną papką, ale także bezwzględnie wykorzystują pracowników. $Z$ podobnych przyczyn darzymy niechęcią hipermarkety. Zapewne niewielu $\mathrm{z}$ nas kupi też podróbki ubrań znanych marek z metką Made in Bangladesh widziane na bazarach. Nie zawsze dzieje się tak z uwagi na niską jakość i nie najlepsze wrażenie, jakie wywołuje wśród otoczenia zniekształcona nazwa którejś z uznanych firm. Jeśli wyznajemy humanitarne i proekologiczne idee, warto zastanowić się także nad tym skąd pochodzi odzież, którą nosimy i jakie koszty - zarówno finansowe, jak i zupełnie odmienne - pociąga za sobą jej produkcja.

Stowarzyszenie Labour Behind the Label to angielski oddział Clean Clothes Campaign - Kampanii Czysta Odzież - międzynarodowej organizacji broniącej praw pracowników sektora odzieżowego w krajach rozwijających się. Potrzeba powołania takiej instytucji wywodzi się z faktu, iż najpopularniejsze marki odzieżowe posiadające światową sieć sklepów, zaopatrują się w szwalniach zlokalizowanych w państwach, w których siła robocza jest niezwykle tania, a waluta na tyle słaba, by można było realizować ogromne zamówienia 
za bardzo niskie ceny, a następnie narzucać na tyle wysoką marżę, by generować ogromne zyski. W tym prostym mechanizmie tkwi jednak podstawowy problem: zyski te nie przekładają się w żadnym stopniu na płace osób zatrudnionych bezpośrednio przy produkcji ubrań. Jako że kraje rozwijające się charakteryzują się niejednokrotnie systemami politycznymi oscylującymi wokół autorytaryzmu lub, w najlepszym wypadku, demokracji nieskonsolidowanej, władza właścicieli fabryk jest absolutna - w praktyce nie istnieją od niej środki odwołania, a próby sprzeciwu lub nawet negocjacji ze strony pracowników (a są nimi głównie kobiety) kończą się masowymi zwolnieniami, co w warunkach ogromnego, strukturalnego bezrobocia i w sytuacji, w której rodziny zazwyczaj posiadają tylko jednego żywiciela, ma katastrofalne skutki. Co gorsza, oficjalne ustawodawstwo w dziedzinie prawa pracy (łącznie z przepisami dotyczącymi tworzenia i działalności związków zawodowych) jest zazwyczaj zgodne z międzynarodowymi normami, co utrudnia walkę z nielegalnymi praktykami. Projekt Oczyśćmy modę, prowadzony przez Labour Behind the Label, postuluje działania na rzecz rzeczywistej poprawy sytuacji pracowników i zakończenia gry pozorów. Kluczowe problemy, które należy rozwiązać, to przede wszystkim podniesienie płac minimalnych tak, aby wystarczały na życie powyżej poziomu ubóstwa. Ponadto należy zapewnić pracownikom - zarówno tym w fabrykach, jak i tym pracujących w miejscu zamieszkania - bezpieczne warunki pracy oraz dostęp do opieki medycznej, nieskutkujący represjami ze strony pracodawcy.

Kampania Czysta Odzież, zmierzając do realizacji powyższych założeń, kieruje się do zróżnicowanych grup odbiorców, z czego wynika różnorodność samych środków. Rządy państw zachodnich proszone są o wywarcie skutecznego wpływu na władze państw rozwijających się, by te egzekwowały przestrzeganie obowiązującego prawa. Zadaniem wielkich międzynarodowych marek oraz firm audytowych miałoby być przeprowadzanie skutecznych niezapowiedzianych kontroli, ukazujących rzeczywistą sytuację w fabrykach. Ostatnią, najliczniejszą i najsilniejszą - bo to oni zamykają koło - grupą, mającą wesprzeć poprawę sytuacji, są sami konsumenci. Kupując odzież znanych firm, takich jak GAP, H\&M, Marks\&Spencer, Benetton czy Zara (m.in. te marki zostały prześwietlone przez Labour Behind the Label na potrzeby projektu Oczyśćmy modę), musimy zdawać sobie sprawę z faktu, iż jedynie kilka procent ceny, którą płacimy za produkt, stanowią koszty jego produkcji - przykładowy T-shirt sprzedawany za 8 funtów, jest produkowany w Indiach za ok. 15 pensów. Suma, którą otrzymują robotnice pracujące w skrajnie trudnych warunkach, wyniszczających zarówno psychicznie, jak i fizycznie, jest jeszcze niższa. Firmy odzieżowe nie podejmują żadnych, 
poza pozornymi, działań, by zmienić sytuację, gdyż jej polepszenie bez podniesienia cen ubrań (a co za tym idzie - utraty części klientów) oznaczałoby zmniejszenie zysków.

Działania organizacji takich jak Kampania Czysta Odzież nie wyznaczają standardów etycznego kupowania. Nie nawołują także do bojkotowania jednych firm na korzyść innych. Mają jedynie na celu zmianę konsumentów z pasywnych odbiorców serwowanej im estetyki na aktywne jednostki, świadomie podejmujące decyzje, upowszechniające je i za ich pomocą wpływające na kształtowanie się rynku. 


\section{Oczyśćmy modę.}

Na jakich płacach opiera się brytyjska elita?

Podsumowanie raportu Labour Behind the Label

\section{Jakie płace kryją się pod metkami?}

Sześć lat temu organizacja Labour Behind the Label (LBL) opublikowała raport zatytułowany „Nosić się lekko: stan płac w przemyśle odzieżowym”. Raport wskazywał, iż robotnicy z całego świata, produkujący dla uznanych brytyjskich marek, żyli poniżej poziomu ubóstwa, co zainteresowało zaledwie kilka firm.

Dowód, iż określona prawem płaca minimalna nie wystarcza nawet na pokrycie potrzeb pojedynczego robotnika, jest przytłaczający - wynikało z raportu. Większość firm nie skupia się na problemie niskich płac, próbując zademonstrować, iż zapłata, która otrzymuja robotnicy, jest wystarczająca. Argument, że nikt nie wie jaka suma w istocie wystarcza do przeżycia, wykorzystuja one jako pretekst do zaniechania działań i ignorowania problemów pracowników oraz konsumentów.

Na początku 2006 roku zdecydowaliśmy, że czas prześwietlić przemysł odzieżowy pod kątem poczynionych postępów. W czasie, w którym ocenialiśmy sytuację bezpośrednio $\mathrm{w}$ miejscach pracy, napisaliśmy także do przedstawicieli najbardziej uznanych firm, dając im możliwość skomentowania informacji, opracowanych na podstawie danych pochodzących z ogólnie dostępnych stron internetowych tychże marek. (...)

Powyższy raport został napisany oraz opublikowany przez organizację Labour Behind the Label - stowarzyszenie wspierające wysiłki pracowników przemysłu odzieżowego, mające na celu poprawę warunków ich pracy. Szkolimy konsumentów, wywieramy nacisk na firmy i agendy rządowe, nagłaśniamy tę kwestię i zachęcamy do międzynarodowej solidarności z robotnikami. Jesteśmy brytyjskim oddziałem międzynarodowego stowarzyszenia Czysta Odzież (Clean Clothes).

\footnotetext{
*Pełen tekst tłumaczenia dostępny jest w drukowanej wersji pisma.
} 